\title{
MANAJEMEN PENGELOLAAN PEMBIAYAAN PENDIDIKAN ISLAM NURUL KAROMAH BANGKALAN
}

\author{
Badruttamam \\ STAI Nazhatut Thullab Sampang \\ Email: tamam.badrut43@yahoo.com
}

\begin{abstract}
Abstrak:
Pendidikan nasional berfungsi mengembangkan kemampuan dan membentuk watak serta peradaban bangsa yang bermartabat dalam rangka mencerdaskan kehidupan bangsa, bertujuan untuk berkembangnya potensi peserta didik agar menjadi manusia yang beriman dan bertakwa kepada Tuhan Yang Maha Esa, berakhlak mulia, sehat, berilmu, cakap, kreatif, mandiri dan menjadi warga negara yang demokratis serta bertanggung jawab. Dalam mewujudkan hal itu semua, maka dibutuhkan sumber daya manusia yang profesional dan anggaran yang memadai. Pembiayaaan pendidikan adalah faktor penting dalam menjamin mutu dan kualitas proses pendidikan. Meskipun pembiayaan pendidikan bukan satusatunya faktor keberhasilan, tanpa adanya pembiayaan yang mencukupi, maka pendidikan yang berkualitas hanya dalam angan-angan. Pada hal dunia pendidikan sedang ditantang untuk menjawab tiga hal: Kemampuan memenuhi kebutuhan, kemampuan mengembangkan hidup yang bermakna dan kemampuan memuliakan hidup. Disisi lain pendidikan juga dihadapkan pada globalisasi, yang ditandai dengan industrialisasi pendidikan sehingga berdampak pada dana anggaran pembiayaan pendidikan. Tujuan kami dalam penulisan artikel ini adalah untuk meneliti dan mengetahui Manajemen Pengelolaan Pembiayaan Pendidikan Islam di Pondok Pesantren Nurul Karomah Galis Bangkalan. Penelitian ini menggunakan jenis penelitian kualitatif, dengan jenis studi kasus. Pengumpulan data dilakukan dengan teknik observasi, wawancara dan studi dokumentasi. Sedangkan teknik analisa data, peneliti menggunakan model analisis interaktif yang mengandung empat komponen yang saling berkaitan, yaitu: pengumpulan data, reduksi data, penyajian data, dan verivikasi data. Hasil penelitian menunjukkan bahwa secara keseluruhan, sumber-sumber dana pendidikan di Ponpes Nurul Karomah Bangkalan pada dasarnya bersumber dari pemerintah, orang tua dan masyarakat. Sumber yang paling utama dalam pembiayaan pendidikan di Ponpes Nurul Karomah Bangkalan berasal dari iuran wajib (SPP) yang dibayarkan siswa kepada sekolah yang telah ditetapkan Ponpes Nurul Karomah Bangkalan. Dalam hal pengelolaan Pembiayaan, pengelolaan Pembiayaan sekolah di Ponpes Nurul Karomah Bangkalan adalah di kelola kepala sekolah, guru berpengalaman (senior) yang telah ditunjuk oleh sekolah yang dibantu tenaga administrasi, dan para anggota komite sekolah. Secara khusus, pengendalian anggaran di Ponpes Nurul Karomah Bangkalan terdiri dari serangkaian kegiatan pemeriksaan dan persetujuan untuk memastikan bahwa: Dana dibelanjakan sesuai rencana, Ada kelonggaran dalam penganggaran untuk pembayaran pajak, Pembelanjaan dilakukan dengan memanfaatkan sumber daya yang tersedia, dan Dana tidak
\end{abstract}


dihabiskan untuk kegiatan-kegiatan yang tidak disetujui atau diberikan kepada pihak penerima tanpa persetujuan.

Kata Kunci: Manajemen, Pengelolaan Pembiayaan, Pendidikan Islam

\begin{abstract}
:
National education function to develop ability and form the character and civilization of dignified nation in order to educate the life of the nation, aims to the development of the potential of learners to become human beings who believe and pious to God Almighty, noble, healthy, knowledgeable, skilled, creative , independent and become a democratic and responsible citizen. In realizing it all, it takes a professional human resources and adequate budget. Education funding is an important factor in ensuring the quality and quality of the educational process. Although education finance is not the only success factor, without sufficient financing, quality education is only in the fantasy. In terms of the world of education is being challenged to answer three things: The ability to meet the needs, the ability to develop a meaningful life and the ability to glorify life. On the other hand education is also faced with globalization, which is characterized by the industrialization of education so that the impact on education budget funding budget. Our goal in writing this article is to examine and know the Management of Islamic Education Financing Management at Pondok Pesantren Nurul Karomah Galis Bangkalan. This research uses qualitative research type, with case study type. Data collection was done by observation, interview and documentation study. While the data analysis technique, the researcher uses an interactive analysis model that contains four interrelated components, namely: data collection, data reduction, data presentation, and data verification. The results showed that overall, the sources of education funds in Ponority Nurul Karomah Bangkalan basically sourced from the government, parents and society. The most important source of education funding in Ponority Nurul Karomah Bangkalan comes from the compulsory fee (SPP) paid by the students to the school that has been established Ponpes Nurul Karomah Bangkalan. In terms of financing management, the management of School Financing in Ponority Nurul Karomah Bangkalan is managed by principals, experienced teachers (seniors) who have been appointed by schools assisted by administrative staff, and members of the school committee. In particular, the budgetary control at the Nurul Karomah Bangkalan Ponpes consists of a series of checking and approval activities to ensure that: Funds are spent according to plan, There is leeway in budgeting for tax payments, Spending is made by utilizing available resources, and Funds are not spent on non- activities that are not approved or granted to the beneficiary without consent.
\end{abstract}

Keywords: Management, Financing Management, Islamic Education. 


\section{Pendahuluan}

Jika anda bertanya apa manfaat pendidikan, maka jawabannya sederhana: Pendidikan membuat orang menjadi lebih baik dan orang baik tentu berperilaku mulia (Plato: 428-347 SM). Kutipan filusuf diatas merupakan pandangan yang sangat idealias yang menganggap bahwa manusia dibentuk oleh dunia ide dan citacita,bukan oleh situasi sosial yang nyata. Pandangan semacam itu menjadi masih memiliki pengikutnya sampai sekarang. Bahwa pendidikan masih dipandang sebagai cara untuk membuat manusia menjadi lebih baik, bijak, dan pendidikan menghasilkan manusia-manusia yang mendukung berjalannya masyarakat yang ideal. ${ }^{1}$

Biaya pendidikan merupakan salah satu komponen masukan instrumental yang sangat penting dalam penyelenggaraan pendidikan. Dalam setiap pencapaian tujuan pendidikan, baik tujuan-tujuan yang bersifat kuatitatif maupun kualitatif, biaya pendidikan memiliki peranan yanga sangat menentukan. Hampir tidak ada upaya pendidikan yang dapat mengabaikan peranan biaya, sehingga dapat bahwa tanpa biaya, proses pendidikan (di sekolah) tidak akan berjalan.

Dalam teori dan praktik pembiayaan pendidikan, baik pada tataran makro maupun mikro dikenal beberapa kategori biaya pendidikan. ${ }^{2}$ Pertama, biaya langsung (direct cost) adalah segala pengeluaran yang secara langsung menunjang penyelenggaraan pendidikan. Kedua biaya tidak langsung (indirect cost) adalah pengeluaran yang tidak secara langsung menunjang proses pendidikan tetapi memungkinkan proses pendidikan tersebut terjadi di sekolah, misalnya biaya hidup siswa, biaya transportasi ke sekolah, biaya jajan, biaya kesehatan dan harga kesempatan (opportunity cost).

Jika kita memotret Sejarah Pendidikan Islam dalam konteks keindonesiaan, maka akan mudah diperoleh sejumlah catatan tentang ke-pondokpesantren-an. Dari berbagai tinjauan para sejarawan muslim, ternyata mereka juga mengakui bahwa sebagai perintis atau cikal bakal Sistem Pendidikan Islam di indonesia adalah dimulai dari Pondok Pesantren. Pengakuan dari para sejarawan muslim ini, tentunya di dukung oleh fakta sejarah yang ada sampai sekarang.

Seperti diketahui bersama, bahawa pertumbuhan atau terbentuknya sistem Pendidikan secara formal, terlebih dahulu dimulai dengan perintisan system pendidikan non-formal, yang berupa pendidikan surau atau pendidikan langgar, yang pada akhirnya lebih besar lagi dan menjadilah Pondok Pesantren. Pondok pesantern di indonesia secara kronologis dapat dijelaskan, pada tahun 1899 di tanah jawa berdirilah pondok pesantern tebu ireng, yang di dirikan oleh K.H. hasim Asy'ari, dan masih banyak yang lainnya.

Pondok pesantren adalah lembaga yang dibangun dari sumbangan swadaya masyarakat yang juga melaksnakan proses belajar-mengajar, baik pengetahuan yang berkaitan dengan keagamaan juga pengetahuan yang berkaitan dengan pengetahuan umum. Bagaimana pengelolaan pembiayaan pendidikan di pondok pesantern tersebut

\footnotetext{
${ }^{1}$ Fatchul Mu'in, Pendidikan Karakter Konstruksi Teoritik dan Praktik, Urgensi Pendidikan Progresif dan Revitalisasi Peran Guru dan Orangtua, Jogjakarta, Ar-Ruzzmedia, 2011, 21.

2 Anwar, Biaya Pendidikan dan Metode Penetapan Biaya Pendidikan. Mimbar Pendidikan, No. tahun $\mathrm{X}, 1991,28$
} 


\section{Definisi Manajemen}

Secara etimologis, kata manajemen berasal dari kata bahasa Latin yaitu dari asal kata manus yang berarti tangan dan agree yang berarti melakukan. Kata-kata itu digabung menjadi kata kerja manage yang artinya menangani. Manage diterjemahkan ke dalam bahasa Inggris dalam bentuk kata kerja to manage, dengan kata benda management, dan manager untuk orang yang melakukan kegiatan manajemen atau mengelola. ${ }^{3}$

Menurut Mary Parker, manajemen adalah seni untuk melaksanakan suatu pekerjaan melalui orang-orang (the art of getting things done through people). ${ }^{4}$ Sedangkan menurut Sondang P. Siagian dalam Arikunto, manajemen adalah keseluruhan proses kerjasama antara dua orang atau lebih yang didasarkan atas rasionalitas tertentu untuk mencapai tujuan yang ditentukan sebelumnya. ${ }^{5}$ Hersey mengatakan "We shall define management as working with and through individual to accomplish organizational goals." 6

Jika pengertian ini diterapkan pada usaha pendidikan yang terjadi pada sebuah organisasi, menurut Arikunto bahwa definisi manajemen pendidikan itu adalah suatu kegiatan atau rangkaian kegiatan yang berupa proses pengelolaan usaha kerjasama sekelompok manusia yang tergabung dalam organisasi pendidikan untuk mencapai tujuan pendidikan yang telah ditetapkan sebelumnya agar efektif dan efisien. ${ }^{7}$

Menurut pandangan ajaran Islam, umatnya dianjurkan untuk melakukan segala sesuatu dengan teratur, rapi, benar, dan tertib. Dalam perkembangan ilmu pengetahuan modern, pekerjaan mengelola sesuatu secara teratur itu merupakan bagian dari ilmu manajemen. ${ }^{8}$ Perhatian Islam terhadap pentingnya manajemen itu menurut Al Hasyimi sebagaimana dikutip oleh Tanjung dapat dipahami dari sabda Nabi SAW yang diriwayatkan oleh Imam Thabrani, ${ }^{9}$ berikut:

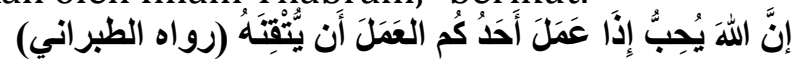

Artinya: "Sesungguhnya Allah sangat mencintai orang yang jika melakukan sesuatu pekerjaan, dilakukan secara itqan (tepat, terarah, jelas dan tuntas)." (HR. Thabrani)

Praktik manajemen lebih diartikan sebagai tindakan mengatur segala sesuatu dengan penuh nggungjawab sesuai dengan tugas yang telah dibebankan untuk

\footnotetext{
${ }^{3}$ Husaini Usman, Manajemen: Teori, Praktek, dan Riset Pendidikan (Jakarta: Bumi Aksara, 2006), hlm. 3.

${ }^{4}$ James A.F. Stoner dan R. Edward Freeman, Manajemen (New Jersey: Prentice Hlml),Terjemahan Indonesia oleh Wilhelmus W. Bakowatun dan Benyamin Molan, Manajemen (Jakarta: Intermedia, 1994), hlm. 10.

5 Suharsimi Arikunto dan Lia Yuliana, Manajemen Pendidikan (Yogyakarta: Aditya Media, 2008), hlm. 3.

${ }^{6}$ Hendyat Soetopo, Manajemen Pendidikan (Bahan Kuliah Manajemen Pendidikan Bagi Mahasiswa S2), (Malang: Pascasarjana-Univ. Negeri Malang, 2001), hlm. 1-2.

7 Suharsimi Arikunto dan Lia Yuliana, Manajemen, hlm. 4.

${ }^{8}$ Abdul Basith, Islam dan Manajemen Koperasi Prinsip dan Strategi Pengembangan Koperasi di Indonesia (Malang: UIN-Malang Press, 2008), hlm. 222.

${ }_{9}$ Didin Hafidhuddin dan Hendri Tanjung, Manajemen Syari'ah dalam Praktik (Jakarta: Gema Insani Press, 2003), hlm. 7.
} 
mencapai tujuan yang telah ditetapkan. Menurut Mulyono, hal itu sesuai dengan isyarat yang ditunjukkan dalam Al Qur'an Surat Az Zalzalah: 7-8.10

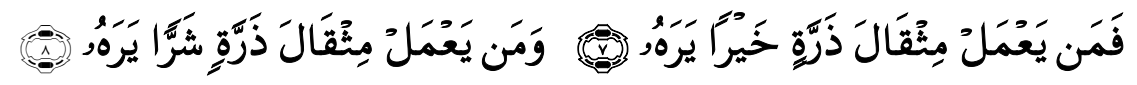

Artinya: Barangsiapa yang mengerjakan kebaikan seberat dzarrahpun, niscaya Dia akan melihat (balasan) Nya. dan barangsiapa yang mengerjakan kejahatan sebesar dzarrahpun, niscaya Dia akan melihat (balasan)nya pula. ${ }^{11}$

Manajemen sebagai suatu ilmu dan teknik untuk mengurus dan mengelola tidak terlepas dari fungsi-fungsi dan kewajiban manusia yang telah ditetapkan Allah SWT, antara lain bahwa manusia berfungi sebagai khalifah dan manusia berkewajiban mengemban amat Allah SWT. Dalam ajaran Islam, manajemen memiliki prinsip atau kaidah yaitu: (1) Prinsip amar ma'ruf nahi mungkar (QS. Ali Imran: 104), (2) Kewajiban menegakkan kebenaran (QS. Al Israa': 18 dan Ali Imran: 60), (3) Menegakkan keadilan (QS. An Nisa': 58 dan Al A'raf: 29), dan (4) Keadilan menyampaikan amanat (QS. An Nisa': 58 dan Al Baqarah: 283)

\section{Pengelolaan Pembiayaan Pendidikan}

Pembiayaan Pendidikan Biaya (cost) merupakan salah satu komponen masukan (instrumental input) yang sangat penting dalam penyelenggaraan pendidikan di sekolah. ${ }^{12}$ Dalam hal ini, biaya dapat diartikan sebagai semua jenis pengeluaran yang berkenaan dengan penyelenggaraan pendidikan. ${ }^{13}$ Secara bahasa biaya (cost) dapat diartikan pengeluaran, dalam istilah ekonomi, biaya/pengeluaran dapat berupa uang atau bentuk moneterlainnya. ${ }^{14}$ Biaya pendidikan dapat juga diartikan sebagai semua jenispengeluaran yang berkenaan dengan penyelenggaraan pendidikan, baikdalam bentuk uang maupun barang dan tenaga (yang dapat dihargakan dengan uang).

Biaya pendidikan merupakan komponen yang sangat penting dalam penyelenggaraan pendidikan. Dapat dikatakan bahwa proses pendidikan tidak dapat berjalan tanpa dukungan biaya. Dalam konteks perencanaan pendidikan, pemahaman tentang anatomi dan problematic pembiayaan pendidikan baik pada tingkat makro, meso, maupun mikro sangat diperlukan. ${ }^{15}$

Pembiayaan pendidikan pada dasarnya adalah menitikberatkan upaya pendistribusian benefit pendidikan dan beban yang harus di tanggung masyarakat. Biaya secara sederhana adalah sejumlah nilai uang yang dibelanjakan atau jasa pelayanan yang diserahkan pada siswa. Pembiayaan pendidikan berhubungan

\footnotetext{
10 Mulyono, Manajemen Administrasi dan Organisasi Pendidikan (Jogjakarta: Ar Ruzz Media, 2008), hlm. 29.

11 Departemen Agama Republik Indonesia, Al-qur'an terjemah.

12 Dedi Supriadi, "Satuan Biaya Pendidikan Dasar dan Menengah", Cet. 6, Remaja Rosdakarya,Bandung, 2006, hlm. 3

${ }^{13}$ Harsono, Pengelolaan Pembiayaan Pendidikan", Pustaka Book Publisher, Yogyakarta, 2007,hlm. 9.

14 J. Hallak, "Analisis Biaya dan Pengeluaran Untuk Pendidikan”, International Institute For Educational Planning, UNESCO, http://www.unesco.co.id/artikel_pendidikan. Akses 5 Mei 2008. 15 Prof. Dr. Dedi Supriadi, Satuan Biaya Pendidikan Dasar dan Menengah, Bandung, RosdaKarya, 2010, iii
} 
dengan distribusi beban pajak dalam berbagai jenis pajak, kelompok manusia serta metode pangalihan pajak ke sekolah. ${ }^{16}$

Menurut Nanang Fatah, pembiayaan pendidikan merupakan jumlah uang yang dihasilkan dan dibelanjakan untuk berbagai keperluan penyelenggaraan pendidikan yang mencakup gaji guru, peningkatan profesional guru, pengadaan sarana ruang belajar, perbaikan ruang, pengadaan peralatan mobile, pengadaan alat-alat dan buku pelajaran, alat tulis, kegiatan ekstrakulikuler, kegiatan pengelolaan pendidikan, dan supervisi pendidikan. ${ }^{17}$

Penjelasan diatas menggambarkan bahwa pembiayaan pendidikan sesungguhnya adalah sebuah analisis terhadap sumber-sumber pendapatan dan penggunaan biaya yang diperuntukkan sebagai pengelolaan pendidikan secara efektif dan efisien dalam rangka mencapai tujuan yang telah ditentukan. Artinya pembiayaan memiliki peranan penting dalam menciptakan lembaga pendidikan yang bermutu seperti yang diharapkan kita bersama.

Dalam pembiayaan pendidikan, selain direct cost dan indirect cost juga ada pembiayaan pendidikan private cost dan social cost. Biaya pribadi adalah biaya pengeluaran keluarga untuk pendidikan atau dikenal juga pengeluaran rumah tangga (hoausehold expenditure). Sedangkan biaya sosial adalah biaya yang dikeluarkan oleh masyarakat untuk pendidikan, baik melalui sekolah maupun melalui pajak yang ra dihimpun oleh pemerintah kemudian digunakan untuk membiayai pendidikan. Biaya yang dikeluarkan pemerintah pada dasarnya termasuk biaya sosial.

Di samping itu, dikenal juga anggaran belanja pendidikan (education budget) yang terdiri atas dua komponen, yaitu: (1). Pendapatan, pemasukan atau penerimaan di satu pihak. (2). Pengeluaran atau belanja. Bila dibedakan berdasarkan sifatnya, maka dikenal biaya rutin (routin/recurrent budget) dan biaya investasi atau pembangunan (investment/development budget). Menurut Caldwell, ${ }^{18}$ dalam sistem anggaran di indonesia, alokasi biaya rutin kepada lembaga-lembaga atau satuan penyelengga pendidikan dituangkan dalam DIK (daftar isian kegiatan).

Dilihat dari sumbernya, biaya pendidikan pada tingkat nasional berasal dari: (1). Pendapatan negera dari sekotor pajak, (2). Pendapatan negara dari sector nonpajak (gas dan non-migas), (3). Keuntungan dari ekspor barang dan jasa, (4). Usaha-usaha negara lainya, termasuk dari investasi saham pada perusahaan negara. (5). Bantuan dalam bentuk hibah dan pinjaman dari luar negeri, baik dari lembaga keuangan internasional seperti; Bank Dunia, ADB, IMF, IDB, JICA. Alokasi dana untuk setiap setiap sector pembangunan, termasuk pendidikan, dituangkan dalam rencana anggaran pendapatandan belanja negara (RAPBN) setiap tahun.

Biaya merupakan suatu unsur yang menentukan dalam mekanisme penganggaran. Penentuan biaya akan memengaruhi tingkat efisiensi dan efektivitas kegiatan dalam suatu organisasi yang akan mencapai suatu tujuan tertentu. Kegiatan yang dilaksanakan dengan biaya yang rendah dan hasilnya

\footnotetext{
${ }^{16}$ Mulyono, MA, Konsep Pembiayaan Pendidikan, Jogjakarta, Ar-Ruzz Media, 2010, 77

${ }^{17}$ Nanang Fatah, Ekonomi dan Pembiayaan Pendidikan, Bandung, Rosdakarya, 2000, 112.

${ }^{18}$ Prof. Dr. Dedi Supriadi, Satuan Biaya Pendidikan Dasar dan Menengah, Bandung, RosdaKarya, 2010,5
} 
mempunyai kualitas yang baik dapat dikatakan kegiatan tersebut dilaksanakan secara efisien dan efektif. ${ }^{19}$

Investasi dalam pembiayaan pendidikan menyangkut pembiayaan guru maupun pegawai, PBM dan KBM, administrasi dan tata usaha, sarana dan prasarana, serta pembiayaan yang berkaitan dengan pemeliharaan termasuk perawatan investaris dan sarana lainnya. Konsep biaya menurut Tilaar (1989:7) merupak keseluruhan dana dan upaya yang diserahkan oleh masyarakat untuk mendapatkan pendidikan dalam kenyataan bahwa kegiatan pendidikan merupakan bentuk dari pelayanan masyarakat.

Dengan demikian, dapat dikatakan bahwa biaya pendidikan adalah beban masyarakat dalam perluasan dan fungsi dari system pendidikan. Produsen, penjual, dan konsumen pendidikan akan menyatukan diri ke dalam satu transanki ekonomi di bidang pendidikan. Biaya dalam pendidikan meliputi biaya langsung (direct cost) dan biaya tidak langsung (indirect cost) biaya langsung adalah biaya yang dikeluarkan untuk keperluan pelaksanaan pengajaran dan kegiatan belajar siswa berupa pembelian alat-alat pelajaran, sarana belajar, biaya transportasi, gaji guru, baik yang dikeluarkan pemerintah, orang tua maupun siswa sendiri.

Sedangkan biaya tidak langsung adalah berupa keuntungan yang hilang (earning forgone $)^{20}$ dalam bentuk biaya kesempatan yang hilang (Opportunity cost) yang dikorbankan oleh siswa selama belajar (Cohn, 1979, Thomas Jone, 1985, Alan Thomas, 1976). Biaya-biaya pendidikank yang dibelanjakan oleh murid, atau orang tua/keluarga dan biaya kesempatan pendidikan dalam penelitian ini tidak termasuk dalam pengertian biaya pendidikan yang sifatnya nonbudgetair. Pengertian pembiayaan pendidikan yang bersifat budgetair, yaitu biaya pendidikan yang diperoleh dan dibelanjakan oleh sekolah sebagai suatu lembaga. Artinya biaya-biaya pendidikan yang bersifat bugetair dan nobudgetair termasuk dalam pengertian biaya pendidikan dalam arti yang luas. ${ }^{21}$

Anggaran biaya pendidikan terdiri dari dua sisi yang berkaitan satu sama lain, yaitu sisi anggaran penerimaan dan anggaran pengeluaran untuk mencapai tujuan-tujuan pendidikan. Anggaran penerimaan adalah pendapatan yang diperoleh setiap tahun oleh sekolah dari berbagai sumber resmi dan diterima secara teratur. Berdasarkan pendekatan unsur biaya (ingredient Approach), pengeluaran sekolah dapat digategorikan ke dalam beberapa item pengeluaran yaitu:

1. Pengeluaran untuk pelaksanaan pelajaran

2. Pengeluaran untuk tata usaha sekolah

3. Pemeliharaan sarana dan prasarana sekolah

4. Kesejahteraan pegawai

5. Administrasi

6. Pembinaan teknis educative, dan

7. Pendataan

\footnotetext{
${ }^{19}$ Imam Machali, Konsep Kebijakan Pembiayaan Pendidikan di Indonesia, makalah tugas mata kuliah kepemimpinan dan politik pendidikan, (Bandung:program studi administrasi pendidikan Sekolah Pascasarjana S3 UPI Bandung, 2008)

${ }^{20}$ Dr. Nanang Fatah, Ekonomi \& Pembiayaan Pendidikan, Bandung, PT Remaja Rosdakarya, 2009, 23

${ }^{21}$ Ibid, 24
} 
Dalam pembiayaan pendidikan, pengeluaran yang tidak memiliki kaitan langsung dengan penyelenggaraan pendidikan dapatlah disebutsebagai pemborosan atau pengeluaran yang mestinya dapat dicegah.Lembaga pendidikan dikatakan boros apabila mengeluarkan dana opersaional, dana pengembangan, dana kesiswaan, dan dana lain melebihidana yang seharusnya diperlukan untuk menyelenggarakan pendidikanpada unit kerjannya. ${ }^{22}$

\section{Fungsi Penganggaran Pembiayaan pendidikan}

Penganggaran merupakan kegiatan atau proses penyusunan anggaran (Budget). Budget merupakan rencana operasional yang dinyatakan secara kuantitatif dalam bentuk satuan uang yang digunakan sebagai pedoman dalam melaksanakan kegiatan-kegiatan lembaga dalam kurun waktu tertentu. Oleh karena itu, dalam anggaran tergambar kegiatan-kegiatan yang akan dilaksanakan oleh suatu lembaga. ${ }^{23}$

Penyusunan anggaran merupakan langkah-langkah positip untuk meralisasikan rencana yang telah disusun. Kegiatan ini melbatkan pimpinan tiaptiap unit organisasi. Pada dasarnya, penyusunan anggaran merupakan negosiasi atau perundingan atau kesepakatan antara puncak pimpinan dengan pimpinan yang dibawahinya dalam menentukan besarnya alokasi biaya suatu penganggaran. Hasil akhir dari satu negosiasi merupakan sutau pernyataan tentang pengeluaran dan pendapatan yang diharapkan daro setiap sumber dana.

Anggaran pada dasarnya terdiri dari dua sisi, yaitu sisi penerimaan dan sisi pengeluaran. Sisi penerimaan atau perolehann biaya ditentukan oleh besarnya dana yang diterima oleh lembaga dari setiap sumber dana. Biasanya, dalam pembahasan pembiayaan pendidikan, sumber-sumber biaya itu dibedakan dalam setiap gologan, pemerintah, masyrakat, orang tua dan sumber-sumber lain. ${ }^{24}$

Besarnya biaya pendidikan yang bersumber dari pemerintah ditentukan berdasarkan kebijakan keuangan pemerintah di tingkat pusat dan daerah seteleh mempertimbangkan skala prioritas.Sedangkan besarnya penerimaan dari masyarakat baik dari perorangan maupun lembaga, yayasan, berupa uang tunai, barang, hadiah atau pinjaman bergantung pada kemampuan masyarakat setempat dalam memajukan pendidikan. Sementara dana yang diterima dari orang tua siswa berupa iuran Bp3 dan SPP yang langsung diterima oleh sekolah atau lembaga pendidikan berdasarkan kemampuan orang tua murid dan dan ditentukan oleh pemerintah atau yayasan.

Sisi pengeluaran terdiri dari alokasi besarnya biaya pendidikan untuk setiap komponen yang harus dibiayai, sebgaian dipergunakan untuk membiayai kegiatan administrasi, ketatausahaan, sarana dan prasarana pendidikan, dan sebagaian diberikan kepada sekolah melalui beberapa saluran. Selain anggaran rutin terdapat anggaran proyek yang setiap tahun disalurkkan oleh Departemen Pendidikan dengan kebutuuhan-kebutuhan sekolah. Anggaran rutin pemerintah pusat dibiayai seluruhnya dari anggaran ruti dan bantuan luar negeri.

\footnotetext{
${ }^{22}$ Harsono, Pengelolaan. Pembiayaan Pendidikan", Pustaka Book Publisher, Yogyakarta, 2007, hlm. 10

${ }^{23}$ Nanang Fatah, Ekonomi \& Pembiayaan Pendidikan, Bandung, PT Remaja Rosdakarya, 2009, 47

${ }^{24}$ Ibid, 48
} 
Anggaran di samping sebagai alat untuk perencanaan dan pengendalian, juga merupakan alat bantu bagi manajemen dalam mengarahkan suatu lembaga menempatkan organisasi dalam possisi yang kuat atau lemah. Oleh karena itu, anggaran juga dapat berfungsi sebagai tolak ukur keberhasilan suatu organisasi dalam mencapai sasaran yang telah ditetapkan.

Apabila melihat perkembangannya, anggaran mempunyai manfaat yang dapat digolongkan kedalam tiga jenis yaitu;

1. Sebagai alat penaksir

2. Sebagai alat otorisasi pengeluaran, dan

3. Sebagai alat efisiensi.

Dalam kaitannya dengan proses penyusunan anggaran ini, Lipham ${ }^{25}$ (1985) mengungkapkan empat fase kegiatan pokok sebagai berikut:

1. Merencanakan anggaran, yaitu kegiatan mengidentifikasi tujuan, menentukan prioritas, menjabarkan tujuan kedalam penampilan operasional yang dapat diukur, menganalisis alternative pencapaian tujuan dengan analisis costaffectivenes dan membuat rekomendasi alternative pendekatan untuk mencapai sasaran.

2. Mempersiapkan anggaran, yaitu menyesuaikan kegiatan dengan mekanisme anggran yang berlaku, bentuknya, ditribusi, dan sasaran program pengajaran perlu dirumuskan dengan jelas. Melakukan inventarisir kelengkapan peralatan dan bahan-bahan yang telah tersedia.

3. Mengelola pelaksanaan anggaran, yaitu mempersiapkan pembukuan, melakukan pembelanjaan dan membuat transaksi, membuat perhitungan, mengawasi pelaksanaan sesuai dengan prosedur kerja yang berlaku serta membuat laporan pertanggung jawaban keuangan.

4. Menilai pelaksanaan anggaran, yaitu menilai bagaimana mencapai sasaran program serta membuat rekomendasi untuk perbaikan anggaran yang akan datang.

Proses penyusunan anggaran memerlukan data yang akurat dan lengkap sehingga semua perencanaan kebutuhan untuk masa yang akan datang dapat diantisipasi dalam rencana anggaran. Banyak faktor yang mempengaruhi penyusunan anggaran pendidikan di lembaga pendidikan, seperti perkembangan peserta didik, inflasi, pengembangan program, dan perbaikan serta peningkatan pendekatan belajar mengajar.

\section{Prinsip dan Prosedur Penyusunnan Anggara Pembiayaan Pendidikan}

Mendudukkan anggaran (RAPBS) sebagai fungsi dan alat dalam perencanaan maupun pengendalian, maka anggaran harus disusun berdasarkan prinsip-prinsip sebagai berikut:

1. Adanya pembagian wewenang dan tanggung jawab yang jelas dalam system dan organisasi.

2. Adanya system akuntasi yang memadai dalam melaksanakan anggaran.

3. Adanya penelitian dan analisis untuk menilai kinerja organisasi.

4. Adanya dukungan dari pelaksana mulai dari tingkat atas sampai yang paling bawah.

${ }^{25}$ Mulyono, MA, Konsep Pembiayaan Pendidikan, Jogjakarta, Ar-Ruzz Media, 2010, 163 
Ke empat butir di atas dapat tercapai jika organisasi dan menajemennya berbentuk kategori sehat. Persoalan penting dalam penyusunan anggaran adalah bagaimana memanfaatkan dana secara efisien, mengalokasikan secara tepat, sesuai dengan skala prioritas. Itulah sebabnya dalam prosedur penyusunan anggaran memerlukan tahapan-tahapan yang sistematik. Tahapan penyusunan anggaran adalah sebagai berikutu: ${ }^{26}$

1. Mengidentifikasi kegiatan-kegiatan yang akan dilakukan selama periode anggaran.

2. Mengidentifikasi sumber-sumber yang dinyatakan dalam uang, jasa, dan barang.

3. Semua sumber dinyatakan dalam bentuk uang sebab anggaran pada dasarnya merupakan pernyataan finansial.

4. Memformulasikan anggaran dalam bentuk format yang telah disetujui dan dipergunakan oleh instansi tertentu.

5. Menyusun usulan anggaran untuk memperoleh persetujuan dari pihak yang berwenang.

6. Melakukan revisi usulan anggaran.

7. Persetujuan revisi usulan anggaran.

8. Pengesahan anggaran.

Agar dapat mengefektifkan pembuatan anggaran (RAPBS), yang sangat bertanggung jawab sebagai pelaksana adalah kepala sekolah atau pimpinan lembaga tersebut. Kepala sekolah harus mampu mengembangkan sejumlah demensi perbuatan administrative. Kemampuan untuk menerjemahkan program pendidikan kedalam ekuivalensi keuangan merupakan hal penting dalam penyusunan anggaran belanja. Kegiatan membuat anggaran belanja bukan pekerjaan rutin atau mekanis, melainkan melibatkan pertimbangan tentang maksud-maksud dari pendidikan dan program.

Di dalam penyusunan anggaran (RAPBS) dlaksanakan dengan melibatkan beberapa unsure, diantaranya 1), kepala sekolah dibantu para wakilnya yang ditetapkan oleh kebijakan sekolah, 2), orang tua murid dalam wadah komite sekolah, 3), Dinas pendidikan kota atau kabupaten, dan 4), pemerintah kota atau kabupaten setempat. Semua komponen ini adalah pihak-pihak yang terkait langsung dengan operasional sekolah sesuai kedudukan dan kapasitasnya.

\section{METODE PENELITIAN}

Penelitian ini dilaksanakan di Ponpes Nurul Karomah Bangkalan Telp (031) 3080069 yang merupakan salah satu Ponpes Salaf yang ada di Kota Bangkalan. Ponpes Nurul Karomah Bangkalan adalah salah satu Pon pes Salay yang tidak hanya mengajarkan keagamaan saja juga didalamnya terdapat lembaga pendidikan formal mulai tingkat pertama (MTs) sampai menengah atas (MA) dan (SMK) yang mengemban multi fungsi yang tidak hanya menyelenggarakan pendidikan agama saja tetapi juga lembaga formal yang secara profesional mencetak santri yang tidak saja paham dalam bidang agama tetapi juga paham dengan ilmu umum seperti yang ada di lembaga pendidikan lainnya.

${ }^{26}$ Nanang Fatah, Ekonomi \& Pembiayaan Pendidikan, Bandung, PT Remaja Rosdakarya, 2009, 49-50 
Penelitian ini menggunakan pendekatan kualitatif berparadigmaPostpositivisme dengan jenis penelitian deskriptif-kualitatif, Bogdan danTaylor mendefinisikan "Metodologi Kualitatif" sebagai prosedur penelitianyang menghasilkan data deskriptif berupa kata-kata tertulis atau lisan dariorang-orang dan perilaku yang dapat diamati. Menurut mereka, pendekatanini, diarahkan pada latar dan individu tersebut secara holistik (utuh). Jadi,dalam hal ini tidak boleh mengisolasikan individu atau oraganisasi ke dalamvariabel atau hipotetis, tetapi perlu memandangnya sebagai bagian dari suatukeutuhan. ${ }^{27}$

Paradigma post-positivisme adalah menempatkan ilmu sosial sepertiilmuilmu alam, yaitu suatu metode yang terorganisir untuk mengkombinasikan logika berpikir deduktif dengan pengamatan empiris, guna menemukan atau memperoleh konfirmasi tentang hukum sebab-akibat yang bisa digunakan untuk memprediksi pola-pola umum gejala sosial tertentu. ${ }^{28}$

Deskriptif-kualitatif adalah penelitian yang data-datanya berupa katakata (bukan angka-angka, yang berasal dari wawancara, catatan laporan,dokumen dan lain-lain) atau penelitian yang di dalamnya mengutamakan untuk pendiskripsian secara analisis sesuatu peristiwa atau proses sebagaimana adanya dalam lingkungan yang alami untuk memperoleh makna yang mendalam dari hakekat proses tersebut. ${ }^{29}$

Dalam penelitian kualitatif, peneliti sendiri atau dengan bantuanorang lain merupakan pengumpul data utama. Dalam hal ini, sebagaimana dinyatakan oleh Lexy Moeloeng (2002), kedudukan peneliti dalam penelitian kualitatif cukup rumit. Peneliti merupakan perencana, pelaksana pengumpulan data, analisis, penafsir data, dan pada akhirnya menjadi pelapor hasilpenelitiannya. Pengertian instrumen atau alat penelitian di sini tepat karena peneliti menjadi segalanya dari keseluruhan proses penelitian. ${ }^{30}$ Berdasarkan pada pandangan di atas, maka pada dasarnya kehadiran peneliti disini disamping sebagai instrumen juga menjadi faktor penting dalam seluruh kegiatan penelitian ini.

\section{Pembahasan dan Hasil Penelitian \\ Manajemen Pengelolaan Pembiayaan Pendidikan Islam}

Ponpes Nurul Karomah Bangkalan dirintis sejak tahun 1991 atas prakarsa KH. Abdul Fatta Ahmad Faqih dan kesepakatan masyarakat. Berdasarkan hasil pertimbangan dan kesepakatan, sekitar bulan September 1991 KH. Abdul Fatta Ahmad Faqih dan para masyarakat bersepakat untuk membangun Ponpes tersebut dan disepakati Ponpes tersebut di bangun di kelurahan Paterongan kecamatan Galis kota Bangkalan, dan diberinama Ponpes tersebut Pondok Pesantren Nurul Karomah.

Mendirikan pondok pesantren ternyata memerlukan banyak biaya untuk keperluannya. Dalam hal ini, kegiatan belajar-mengajar baik pelajaran teori maupun praktek masih terjadi masalah mengenai tempat dan biayanya. Adapun sistem proses belajar mengajar menggunakan kurikulum pesantren salaf, yakni

\footnotetext{
${ }^{27}$ Lexy Moeloeng, Metode Penelitian Kualitatf, (Bandung: PT Remaja Rosdakarya, 2000),hlm. 5

${ }^{28}$ Agus Salim, "Teori dan Paradigma Penelitian Sosial", Yogyakarta, Tiara Wacana, 2001, hlm18

${ }^{29}$ Nana Sudjana, Metode statistik, (Bandung: Tarsito, 1989), hlm. 203

${ }^{30}$ Lexy Moeloeng, Metode Penelitian Kualitatf, (Bandung: PT Remaja Rosdakarya, 2000), 121
} 
memakai kitab klasik seperti: Ikhyak ulemuddin, Bulugum Muaram, Dhurrotun Nasihin, Sullam taufik, Ngaji Diniyah, Tafsir Jalalen, Adzkar.

Adapun pelaksanaan program ma'had dilaksanakan sebagai berikut: untuk pengajian kitab Ikhyak ulumuddin dan Bulugul muaran dilaksanakan ba'da shalat dhuzur, dan pengajian kita Sullam taufik dan Durruton naasihin dilaksanakan ba'da ashar. Sedangkan habis shalat magrib pengajian diniyah adapun kitab yang dibahas adalah kitab nahwu shorrof dan I'lal. Sedangkan habis shalat isyak diadakan belajar bersama, dan pada hari sabtu pengajian kitab tafsir al-jelalain. Demikianlah kegitan proses belajar mengajar setiap hari di ponpes Nurul Karomah.

Sejalan dengan pergantian waktu Ponpes ini tidak hanya mengajarkan tentang keagamaan saja akan tetapi juga membuka lembaga pendidikan formal MTs, Madrasah Aliyah dan SMK. Ini dilaksanakan karena permintaan masyarakat untuk membuka lembaga formal tersebut. Kegiatan proses belajar di laksanakan pagi hari dalam satu lokasi di Ponpes Nurul Karomah. Adapun tenaga pengajar sebagian besar dari alumni Ponpes tersebut dan juga dari tenanga pengajar dari pemerintah, baik di bawah naungan Kemendikbud dan Kemenag kota Bangkalan.

Ponpes Nurul Karomah Bangkalan merupakan Ponpes yang beridiri di lingkungan masyarakat yang sedikit banyak paham tentang ilmu pengetahu an sehingga Ponpes ini keberadaannya menjadi strategis untuk mengembangkan pendidikan. Ponpes menerapakan dua sistem, yakni siswa yang sekolah di lembaga tersebut bisa mukim (menetap) di pondok dan siswa kalong (selesai pulang).

Keberadaan Ponpes ini sebenarnya bisa dikatan cukup strategis karena banyak masyarakat yang menyekolahkan putra dan putrinya di Ponpes sehingga Ponpes lembaga pendidikan ini tidak sepi dari santri. Seperti data yang di dapat peneliti ternyata jumlah santri tingkat MTs 40 orang angakatan 2017, MA 35 Orang dan SMK 40 orang. ${ }^{31}$ Inilah yang menjadi PR Ponpes Nurul Karomah untuk meningkatkan kualitas pendidikan kedepannya.

Adapun sumber biaya yang di kelola oleh lembaga ini berasal dari swadaya masyarakat pemerintah dan SPP siswa atau santri. Bantuan dari pemerintah berupa dana Bantuan Operasional Sekolah (BOS) sedang kan dari swadaya masyarakat berupa hibah. Biaya pendaftaran di lembaga ini relative murah dengan riang berikut ${ }^{32}$ :

\begin{tabular}{|l|l|l|l|l|l|}
\hline NO & \multicolumn{1}{|c|}{ Uraian } & Pem. & \multicolumn{1}{|l|}{$\begin{array}{l}\text { Iuran } \\
\text { Siswa }\end{array}$} & Lain-lain & Jumlah \\
\hline $\begin{array}{l}\text { Uang masuk } \\
\text { ponpes }\end{array}$ & 100.000 & & 200.000 \\
\hline $\begin{array}{l}\text { Uang msk } \\
\text { MTS\&spp, lks } \\
\text { Uang msk MA\& } \\
\text { spp }\end{array}$ & 150.000 & & 400.000 \\
\hline Spp Mts/bulan & & 200.000 & & 500.000 \\
\hline
\end{tabular}

${ }^{31}$ Data diperoleh wawancara Ust Subairi salah satu pengurus Ponpes Nurul Karomah, tanggal, 12 Juni 2018

32 Data diperoleh wawancara dengan salah satu pengurus Ponpes Nurul Karomah, tanggal, 12 Juni 2018 


\begin{tabular}{|l|l|l|l|l|}
\hline Spp MA/bulan & & 40.000 & & 50.000 \\
\hline $\begin{array}{l}\text { Imtihan bg yg } \\
\text { mukim }\end{array}$ & & & 100.000 & 150.000 \\
\hline $\begin{array}{l}\text { Imtihan bg yg } \\
\text { non mukim }\end{array}$ & $\begin{array}{l}\text { Uang ujian } \\
\text { smesteran, Mts }\end{array}$ & 30.000 & 75000 & 7.5000 \\
\hline $\begin{array}{l}\text { Uang ujian } \\
\text { smtrn MA Ujian }\end{array}$ & & 40.000 & & 50.000 \\
\hline $\begin{array}{l}\text { Uang } \\
\text { Smster SMK }\end{array}$ & 45.000 & & 0 \\
\hline Wisuda MA & & & 200.000 & 75.000 \\
\hline Wisuda SMK & & & 200.00 & 1.000 .000 \\
\hline Wisuda Mts & 137.500 .000 & 6.40 .000 & 200.000 & 700.000 \\
\hline Dana Bos & & & $\begin{array}{l}20.000 .000 \\
\text { /bln }\end{array}$ & $\begin{array}{l}138.140 .00 \\
0\end{array}$ \\
\hline Gaji guru & & & & \\
\hline
\end{tabular}

Data diatas jika kita pahami sangat relative murah dari pembiayaan lembaga pendidikan yang lain yang ada di kota Bangkalan ini. Yang menjadi menjadi pertanyaan di benak kita apakah dengan dana yang sederna tersebut proses belajar mengajar di Ponpes berjalan dengan baik. Sebagaimana data yang peneliti peroleh dan seperti yang diungkapkan ustad Subairi: ya, meskipun bermodal pembiayaan yang sederhana dan terkadang kekurangan proses belajar mengajar di Ponpes ini tetap berjalan seperti biasanya. ${ }^{33}$

Bagaimana mungkin sebuah lembaga pendidikan proses belajar mangajar akan berjalan normal tanpa di sokong pembiayaan yang memadai. Oleh sebab itu, Ponpes Nurul Karomah berusaha dengan sungguh-sungguh untuk dapat melaksanakan proses belajar berjalan dengan lancar

Kebijakan pendidikan yang dikembangkan oleh pemerintah (pusat dan daerah) pada era otonomi daerah yang mengacu kepada UU No. 22 tahun 1999 tentang pemerintahan daerah serta berbagai perangakat peratuaran yang meyertainya, akan menentukan kinerja sistem pendidikan, baik pada tataran makro maupun mikro.

Keuangan dan pembiayaan pendidikan merupakan salah satu sumber daya yang secara langsung menunjang efektivitas dan efisiensi pengelolaaan pendidikan. Hal tersebut lebih terasa lagi dalam penerapan MBS, yang menuntut kemampuan, dan mengevaluasi serta mempertanggungjawabkan pengelolaan secara transparan kepada masyarakat dan pemerintah.

Keuangan dan pembiayaan pendidikan sangat menentukan ketercapaian tujuan pendidikan sekolah, yang memerlukan sejumlah investasi dan anggaran pemerintah dan dana masyarakat. Investasi tersebut harus dikelola secara efisien

33 Ustadah Fitria, adalah salah pengajar di ponpes tersebut dan juga alumni ponpes tersebut yang oleh pengasuh diberikan kepercayaan untuk mengamalkan ilimu yang telah didapat selama mondok di ponpes tersebut. dan selama mengabdi di ponpes tersebut ustad arip merasa apa senang dan gembira. Petikan kalimat peneliti dapatkan pada tanggal, 13 Juni 2018. 
dan efektif dan diarahkan langsung terhadap pencapaian tujuan. Hal ini merupakan kegiatan manajemen keuangan yang mengatur penerimaan, pengalokasian, dan pertanggung jawaban keuangan untuk menunjang pelaksanaan program pengajaran. Berdasarkan hasil wawancara dan pengamatan peneliti Ponpes Nurul Karomah Bangkalan, secara keseluruhan, sumber-sumber dana pendidikan di Ponpes Nurul Karomah Bangkalan pada dasarnya bersumber dari pemerintah, orang tua dan masyarakat. Sumber yang paling utama dalam pembiayaan pendidikan di Ponpes Nurul Karomah Bangkalan berasal dari iuran wajib (SPP) ${ }^{34}$ yang dibayarkan siswa kepada sekolah yang telah ditetapkan Ponpes Nurul Karomah Bangkalan.

Siswa atau calon siswa yang mau masuk di Ponpes Nurul Karomah Bangkalan harus mengeluarkan biaya baik itu biaya langsung maupun tak langsung, yang besarnya tergantung pada pembebanan oleh Ponpes Nurul Karomah Bangkalan dan kondisi ekonomi dimana siswa itu tinggal terutama untuk biaya tidak langsung. Sebagai Ponpes Nurul Karomah Bangkalan yang menyelenggarakan pendidikan formal juga menggali dan mencari sumber-sumber dana dari $\mathrm{p}$ ihak masyarakat, baik secara perorangan maupun secara melembaga, baik di dalam maupun di luar negeri, sejalan dengan semangat globalisasi, Ponpes Nurul Karomah Bangkalan bekerja sama dengan dunia industri untuk dapat memberikan bantuan dana pada Ponpes Nurul Karomah Bangkalan, hal tersebut sesuai dengan upaya yang dilakukan oleh Pengasuh dan Pengurus Ponpes dalam menggalang atau menghimpun dana dari kelompok masyarakat. Selain dana yang bersumber dari Siswa dan kerjasama dengan dunia industri, Ponpes Nurul Karomah Bangkalan mendapatkan dana dari pemerintah. Pemerintah sesuai dengan kebijakannya juga memberikan dana kepada Ponpes Nurul Karomah Bangkalan baik sifatnya rutin maupun insidental yang besarnya sesuai dengan ketersediaan anggaran pemerintah.

Jumlah dana yang diterima oleh Ponpes Nurul Karomah Bangkalan pada dasarnya merupakan salah satu komponen pembiayaan pendidikan, dan komponen ini akan menjadi pertimbangan dalam menentukan pembelanjaan yang akan dilaksanakan. Ukuran penerimaan adalah kecukupan, dalam arti apakah dana yang diperoleh akan cukup untuk membiayai kegiatan pendidikan, sementara itu prinsip yang diterapkan Ponpes Nurul Karomah Bangkalan dalam membelanjakan adalah efektivitas dan efisiensi. Prinsip efisiensi mengandung arti bahwa pembelanjaan dilakukan dengan pengorbanan yang minimal dalam melaksanakan suatu kegiatan pendidikan, sedangkan prinsip efektivitas mengandung makna bahwa pembelanjaan yang dilakukan dapat menjadi upaya yang tepat dalam mencapai tujuan pendidikan.

Dana yang diperoleh Ponpes Nurul Karomah Bangkalan dari berbagai sumber tersebut digunakan untuk kepentingan Ponpes dan sekolah, khususnya kegiatan belajar mengajar secara efektif dan efisien. Sehubungan dengan itu, setiap perolehan dana, pengeluarannya harus didasarkan pada kebutuhan-kebutuhan yang telah disesuaikan dengan rencana anggaran pembiayaan sekolah (RAPBS) Ponpes Nurul Karomah. Pembuatan Rencana Anggaran Pendapatan dan Belanja Sekolah (RAPBS) Ponpes Nurul Karomah Bangkalan berdasarkan pada rencana

34 Data diperoleh wawancara Ustad Subeiri salah satu pengurus Ponpes Nurul Karomah, tanggal, 25Juni 2018 
pengembangan Ponpes dan sekolah dan merupakan bagian dari rencana operasional tahunan. Penyusunan RAPBS Ponpes Nurul Karomah Bangkalan melibatkan Pengasuh kepala sekolah, guru, komite sekolah, dan komunitas sekolah. Ponpes Nurul Karomah Bangkalan meliputi penganggaran untuk kegiatan pengajaran, materi kelas, pengembangan profesi guru, renovasi bangunan Ponpes dan sekolah, pemeliharaan, buku, meja dan kursi. ${ }^{35}$

Dalam hal pengelolaan anggaran, pengelola anggaran sekolah di Ponpes Nurul Karomah Bangkalan adalah kepala sekolah, guru berpengalaman (senior) yang telah ditunjuk oleh sekolah yang dibantu tenaga administrasi, dan para anggota komite sekolah. Secara khusus, pengendalian anggaran di Ponpes Nurul Karomah Bangkalan terdiri dari serangkaian kegiatan pemeriksaan dan persetujuan untuk memastikan bahwa:

1. Dana dibelanjakan sesuai rencana,

2. Ada kelonggaran dalam penganggaran untuk pembayaran pajak,

3. Pembelanjaan dilakukan dengan memanfaatkan sumber daya yang tersedia, dan

4. Dana tidak dihabiskan untuk kegiatan-kegiatan yang tidak disetujui atau diberikan kepada pihak penerima tanpa persetujuan.

Pengelola anggaran Ponpes dan sekolah di Ponpes Nurul Karomah Bangkalan membelanjakan uang sesuai alokasi dana yang direncanakan. Setiap perubahan anggaran disetujui oleh Pengasuh dan kepala sekolah bila memang harus ada perubahan dalam tahun berjalan. Dalam pengelolaan dana, Ponpes Nurul Karomah menggunakan PSAK (Prinsipprinsip Standar Akuntansi) dengan model pengelolaan keuangannya menggunakan metode cash flow.

Prinsip-prinsip tersebut pada dasarnya dibuat untuk mengendalikan penerimaan dan pengeluaran, serta menyajikan laporan keuangan yang lengkap, akurat, dan terkini. Pengelolaan akuntansi keuangan dengan metoda cash flow (aliran kas) merupakan pendekatan pengelolaan keuangan yang praktikal dan sesuai untuk lembaga pendidikan sekolah atupun unit usaha kecil yang pola pengelolaan keuangannnya masih sederhana. Pengertian cash flow adalah aliran kas perusahaan yang secara riil diterima dan dikeluarkan oleh perusahaan untuk keperluan operasi, pendanaan, dan investasi. Aliran kas yang masuk ke perusahaan disebut dengan cash in flow, sedangkan aliran kas yang keluar dari perusahaan dinamai cash out flow. ${ }^{36}$

Penjelasan diatas menunjukan bahwa pengelolaan dana pendidikan perlu dilakukan dengan baik melalui langkah-langkah sistematis sesuai dengan prinsipprinsip manajemen. Ini berarti bahwa melihat masalah biaya dan kualitas pendidikan aspek manajemen pembiayaan pendidikan perlu diperhatikan dengan seksama, agar terhindar dari pemborosan dimana biaya yang besar ternyata tidak berdampak apapun pada kualitas pendidikan.

\section{Kesimpulan}

\footnotetext{
35 Data diperoleh wawancara dengan Ustad Sholikin Ketua pengurus Ponpes Nurul Karomah, tanggal, 25 Juni 2012

36 Data diperoleh wawancara dengan Ustadah Maria salah satu pengurus Ponpes Nurul Karomah, bagian bendahara tanggal, 25 Juni 2018
} 
Pembiayaan Pendidikan Biaya (cost) merupakan salah satu komponen masukan (instrumental input) yang sangat penting dalam penyelenggaraan pendidikan di sekolah. Dalam hal ini, biaya dapat diartikan sebagai semua jenis pengeluaran yang berkenaan dengan penyelenggaraan pendidikan. Secara bahasa biaya (cost) dapat diartikan pengeluaran, dalam istilah ekonomi, biaya/pengeluaran dapat berupa uang atau bentuk moneterlainnya. Biaya pendidikan dapat juga diartikan sebagai semua jenispengeluaran yang berkenaan dengan penyelenggaraan pendidikan, baik dalam bentuk uang maupun barang dan tenaga (yang dapat dihargakan dengan uang).

Ponpes Nurul Karomah Bangkalan, secara keseluruhan, sumber-sumber dana pendidikan di Ponpes Nurul Karomah Bangkalan pada dasarnya bersumber dari pemerintah, orang tua dan masyarakat. Sumber yang paling utama dalam pembiayaan pendidikan di Ponpes Nurul Karomah Bangkalan berasal dari iuran wajib (SPP) yang dibayarkan siswa kepada sekolah yang telah ditetapkan Ponpes Nurul Karomah Bangkalan.

Dalam hal pengelolaan anggaran, pengelola anggaran sekolah di Ponpes Nurul Karomah Bangkalan adalah kepala sekolah, guru berpengalaman (senior) yang telah ditunjuk oleh sekolah yang dibantu tenaga administrasi, dan para anggota komite sekolah. Secara khusus, pengendalian anggaran di Ponpes Nurul Karomah Bangkalan terdiri dari serangkaian kegiatan pemeriksaan dan persetujuan untuk memastikan bahwa:

1. Dana dibelanjakan sesuai rencana,

2. Ada kelonggaran dalam penganggaran untuk pembayaran pajak,

3. Pembelanjaan dilakukan dengan memanfaatkan sumber daya yang tersedia, dan

4. Dana tidak dihabiskan untuk kegiatan-kegiatan yang tidak disetujui atau diberikan kepada pihak penerima tanpa persetujuan.

\section{Daftar Pustaka}

Anwar, (1991) Biaya Pendidikan dan Metode Penetapan Biaya Pendidikan. Mimbar Pendidikan, No. tahun X.

Arikunto Suharsimi dan Yuliana Lia, (2008) Manajemen Pendidikan. Aditya Media, Yogyakarta.

Basith Abdul, (2008) Islam dan Manajemen Koperasi Prinsip dan Strategi Pengembangan Koperasi di Indonesia. UIN-Malang Press, Malang.

Departemen Agama Republik Indonesia, Al-qur'an terjemah.

Hafidhuddin Didin dan Tanjung Hendri, (2003) Manajemen Syari'ah dalam Praktik Gema Insani Press, Jakarta.

Fatah Nanang, (2000) Ekonomi dan Pembiayaan Pendidikan,Rosdakarya, Bandung.

Harsono,(2007) Pengelolaan Pembiayaan Pendidikan", Pustaka Book Publisher, Yogyakarta. 
Hallak, (2011) “Analisis Biaya dan Pengeluaran Untuk Pendidikan”, International Institute For Educational Planning, UNESCO, http://www.unesco.co.id/artikel pendidikan. Akses 22 Juni 2011

Koentjaraningrat, (1997) Metode-metode Penelitian Masyarakat, PT Gramedia Pustaka Utama, Jakarta.

Mu'in Fatchul, (2011) Pendidikan Karakter Konstruksi Teoritik dan Praktik, Urgensi Pendidikan Progresif dan Revitalisasi Peran Guru dan Orangtua, Jogjakarta, ArRuzzmedia.

Mulyono, (2010) Konsep Pembiayaan Pendidikan, Ar-Ruzz Media, Jogjakarta.

---------- (2008) Manajemen Administrasi dan Organisasi Pendidikan. Ar Ruzz Media, Yogyakarta.

Machali Imam, (2008) Konsep Kebijakan Pembiayaan Pendidikan di Indonesia, makalah tugas mata kuliah kepemimpinan dan politik pendidikan,: Program studi administrasi pendidikan Sekolah Supriadi Dedi, (2006) "Satuan Biaya Pendidikan Dasar dan Menengah", Cet. 6, Remaja Rosdakarya, Bandung.

Moeloeng Lexy, (2000) Metode Penelitian Kualitatf, PT Remaja Rosdakarya, Bandung.

Supriadi Dedi, (2010) Satuan Biaya Pendidikan Dasar dan Menengah, RosdaKarya, Bandung.

Pascasarjana S3 UPI Bandung, Bandung

Sudjana, Nana,(1989) Metode statistik,Tarsito, Bandung.

Salim Agus, (2001)“Teori dan Paradigma Penelitian Sosial”, Yogyakarta, Tiara Wacana,

Stoner James A.F. dan Freeman R. Edward,(1994) Manajemen (New Jersey: Prentice Hlml),Terjemahan Indonesia oleh Wilhelmus W. Bakowatun dan Benyamin Molan, Manajemen Intermedia, Jakarta.

Usman Husaini, (2006) Manajemen: Teori, Praktek, dan Riset Pendidikan Bumi Aksara, Jakarta. 